\title{
Value Stream Analysis in Military Logistics: The Improvement in Order Processing Procedure
}

\author{
Raquel Acero ${ }^{1, *(\mathbb{D})}$, Marta Torralba ${ }^{2} \mathbb{D}$, Roberto Pérez-Moya ${ }^{3}$ and José Antonio Pozo ${ }^{3}$ \\ 1 Department of Design and Manufacturing Engineering, Universidad de Zaragoza, María de Luna 3, \\ 50018 Zaragoza, Spain \\ 2 Centro Universitario de la Defensa, Academia General Militar, Ctra. de Huesca s/n, 50090 Zaragoza, Spain \\ 3 Mando de Apoyo Logístico del Ejército, Ejército de Tierra, 28004 Madrid, Spain \\ * Correspondence: racero@unizar.es
}

Received: 11 November 2019; Accepted: 19 December 2019; Published: 21 December 2019

\begin{abstract}
Military logistics is a complex process where response times, demand uncertainty, wide variety of material references, and cost-effectiveness are decisive for combat capability. The demanding flexibility can only be achieved by improving supply chain management (SCM) to minimize lead times. To cope with these requirements, lean thinking can be extended to military organizations. This research justifies and proposes the use of lean methodologies to improve logistics processes with the case study of a military unit. In particular, the article presents the results obtained using value stream mapping (VSM) and value stream design (VSD) tools to improve the order processing lead time of spare items. The procedure starts with an order generation from a military unit that requests the material and ends before transportation to the final destination. The whole project was structured, considering the define-measure-analyze-improve-control (DMAIC) problem-solving methodology. The results show that the future state map might increase added-value activities from $44 \%$ to $70 \%$. After implementation, it was demonstrated that the methodology applied reduced the lead-time average and deviation up to $69.6 \%$ and $61.9 \%$, respectively.
\end{abstract}

Keywords: military logistics; lean management; DMAIC; VSM-VSD

\section{Introduction}

Logistics and supply chain management (SCM) propose a challenging issue for worldwide organizations. In particular, military logistics [1] is a specific case where the ability to provide human and material resources is crucial in terms of minimum time, unpredictable quantity, and variable location of new armed conflicts. According to [2], five main aspects are different between military and consumer supply: large numbers of different types of items, variable demand, supply management considering priority matters (e.g., medical supplies, subsistence, repair part), the necessity of equipment and supply readiness, and different theatres characterized by moving points. Hence, it is difficult to manage inventories under these market conditions, which could mean either overstocking or delay. Additionally, two more factors must be considered in military applications. The first one is related to the available funding that may be limited for each nation. The second one is the supply importance if it supposes a risk factor to the human lives of combatants and civilians. In other words of the American report [3], the strategic approach of military logistics should be focused on the improvement in processes, information systems, organizational structures, and advances in distribution and transportation technologies. Thus, precise time, capacity, and efficiency of delivery to the operations theatres are required for Armed Forces. As it is explained in [4], in 2001, the United States Department of Defense (DoD) began the standardization process of its SCM using the supply chain operations reference (SCOR) model $[5,6]$ as its framework. This approach focused on the increase 
in the supply chain reliability by synchronizing each element internally and externally, forecasting the demand and managing inventories and assets efficiently.

To minimize response times and to assure the required flexibility avoided wastes, the lean philosophy can be extended to supply chain management in military organizations. For example, the United States Department of Defense (DoD) has been working intensively together with service providers and supporting contractors to introduce and apply lean principles into their organizations to optimize internal lead times [7]. The origin of lean philosophy is generally attributed to the practices developed from the TPS or Toyota Production System [8,9], pioneered by Taiichi Ohno [10] and Shigeo Shingo [11]. Their lean principles related to philosophy, processes, people, partners, and problem-solving allow organizations the implementation of lean thinking at different levels. Moreover, TPS has influenced not only manufacturing concepts but also supply chain management ones [12-14]. The concept of lean supply is described in $[15,16]$ as an operating attitude that needs to be changed in relation to suppliers so that the effect of associated costs to non-perfect processes will not be limited to the location of the execution. This approach targets long-term customer satisfaction. Thus, supply chain optimization is possible according to the three main TPS goals: best quality, lowest cost, and shortest lead-time, which are achieved by continuous improvement and increasing operations' added value.

This work evaluates the use of lean methodologies and their application to military logistics functions, focusing on supply chain management processes for spare parts. We present a case study to improve military material order processing procedures by implementing value stream analysis methodologies. SCOR model performance metrics, such as order fulfillment lead time and delivery performance, are assessed. To structure the research project, the define-measure-analyze-improve-control (DMAIC) Six Sigma methodology was followed [17]. Its aim is aligned to continuous improvement and lean thinking [18] and integrates the approaches of lean and Six Sigma as presented in [19-21].

\section{Background}

\subsection{Military Logistics and Processes}

The supply chain management concept is a horizontal strategic function that encompasses all the operations of the supply chain between customers and suppliers, distribution, manufacturing, procurement, and planning, to give an integrated answer to the competitive difference of the organizations. Viewed from the life cycle perspective, military logistics is the bridge between the deployed forces and the industrial base that produces the weapons and materials that the forces need to accomplish their mission [22]. The North Atlantic Treaty Organization or NATO defines logistics in [23] as the science of planning, coordinating, and carrying out the movement and maintenance of forces, which covers aspects of military operations related to material, transport of personnel, acquisition of facilities and services, and medical service support.

Three main aspects of logistics need to be highlighted in the military logistics cycle: production or acquisition logistics focused on the procurement of the material; in-service logistics that links production and consumer logistics and comprises functions associated with receiving, storing, distributing, and disposing material to the force; consumer or operational logistics that concerns the reception, storage, transport, maintenance, and disposal of the material, including the provision of support and services. Depending on the strategic, operational, or tactical level of the logistic function approached, different activities are encompassed. There are also multiple logistic functions identified in the military field. Nevertheless, we will focus on the material supply logistic function in this work, which includes the determination of stock levels, provisioning, distribution, and replenishment restricted in this case to operational and tactical levels.

The organization of this research study is referred to as $A B C$ throughout this paper due to non-disclosure requirements. Particularly, $A B C$ is a military unit of the Spanish Army in charge of the supply and maintenance of a wide range of items used as spare parts. Therefore, these supply and maintenance processes could be classified into operational and tactical levels. There are several 
particularities that make the military supply especially critical [2]. In brief, the large number of different material references, variable demand and multiple ordering locations, priority requirements and high material availability are reasons to justify the necessity of optimizing the material order processing procedure and its metrics in $\mathrm{ABC}$. The process to be optimized starts with an order generation from a deployed military unit that requests the material to $A B C$, and it ends before the transportation to the final destination [24]. Additionally, for the ABC product families, a critical aspect need to be highlighted, i.e., the high rate of technological obsolescence of the material.

The importance of spare parts management in organizations has been addressed in the literature. Supply chain management for spare parts is described in [25] as a multi-echelon supply chain, where the differences in size generate demand peaks and, thus, a very variable and lumpy demand pattern. The authors propose an algorithmic solution considering the sources of demand variability, a probabilistic forecast, and inventory management. The importance of spare parts logistics is mostly related to their inventory management, whose main differences to general inventory management are the low demand and a wide variety of items with no predictable demand. The authors in [26] discuss the basic principles affecting the management of spare parts logistics, which affect the strategic choices and related policies in this area. The most relevant control characteristics of spare parts (criticality, specificity, demand pattern, and value) are first identified to define further supply chain management strategies. The Norwegian Defense has used a systematic approach based on OPUS10 for spare parts management optimization in procurement projects. This case study was reviewed by analyzing empirical data to evaluate the suitability of the theoretical system approach used through OPUS10 in terms of spare parts costs and availability [27]. Furthermore, in [28], the importance of the supply chain as a source of commercial-military integration linking defense production to the wider economy is demonstrated.

\subsection{Lean Methodologies and Tools}

Lean thinking promotes a continuous-improvement culture with its tools and practices widely applied in different sectors and organizations. Lean is one of the most influential recent paradigms in manufacturing, also considered in relation to another promising trend as Industry 4.0 [29]. It has expanded beyond the original application to other areas and sectors, either public or private. As before mentioned, the origin of lean philosophy generally attributed to the practices developed from the Toyota production system [8,9]. One of the first studies mentioning lean concepts comparing automotive manufacturing plant performance in Japan, the United States, and Europe was [30]. Since then, lean practices have been developed and extended worldwide. The lean approach, its techniques, and limitations were revised in the literature [31,32], remarking the necessity of an adequate implementation sequence [33] and the effect of large-scale strategic management in lean deployment [34]. Several efforts were focused on the measurement of leanness by considering different dimensions $[35,36]$. The evolution of lean was also addressed in [37] not only as a concept but also in terms of its application.

The link between lean and the supply chain evolved from the value stream concept [38], and the concept of pull was extended beyond single manufacturing facilities to include the up- and downstream partners. Focusing on supply chain management, different methodologies have been applied for logistics optimization purposes. Combined approaches of lean and agile methodologies applied to SCM are also found in [39] for the textile and apparel sector, where short product lifecycles, high volatility, low predictability, and a high level of impulse purchase have paramount importance. In addition, in [40], the existence of hybrid supply chain strategies with a mixed portfolio of products and markets where neither pure agile or lean strategies apply is remarked. Lean works best in high volume, low variety, and predictable environments; meanwhile, agile suits for less predictable environments, with volatile demand and high requirements for variety. An integrated proposal of both methodologies is proposed in [41] and in [42] supported by a personal computer (PC) supply chain case study.

In relation to lean logistics in defense, there is scarce literature available. The concept of pull systems applied to military logistics was questioned by the authors in [43]. A large accumulation of stocks in intermediate distribution points supposes the reduction of effectiveness maneuverability of 
the deployed combat forces. On the other hand, the "Just-in-Time" approach could bring an associated risk of late or even null deliveries, given the possible actions of the enemy. Bean et al. [44] discussed the inventory management in the uncertain environment of military support. Considering stocks, additional problematic aspects are related to damage, degradation, and obsolescence of the material, which mean monetary losses at the end.

\section{Value Stream Practices}

The origin of the value stream analysis, i.e., value stream mapping (VSM) and value stream design (VSD) methods, is the Toyota production system. It is a visual tool and facilitates the continuous improvement in processes efficiency with the identification of value-adding activities and the elimination or modification of adding waste tasks. Early publications showed during the 1990s the benefits of value stream analysis as an operational approach for a lean enterprise and defined specific lean tools for minimizing the seven wastes [45]. Although it is a simple and standardized methodology, it presents limitations and challenges, as was reviewed in [46]. Generally, four steps should be established to improve a process by using VSM and VSD tools. First, a particular process for a product or product family should be selected due to particular factors (e.g., criticality, impact, efficiency, etc.). Then, value stream mapping starts analyzing and drawing the current state map of the process, where activities with added and non-added value are exposed. The different activities, materials, and information flows are related and schematized in flow diagrams after walking along the actual process. The main key performance indicators (KPIs) of the process, such as lead-time, are usually measured before VSM to establish a reference point of the initial situation. Value-added, non-value added activities, and inventories are evaluated in terms of their time contribution to the lead-time of the process. After VSM, value stream design outlines the idealized solution for improving the studied process to reduce waste, lead-time, work in process (WIP), and inventories. At this phase, KPIs are measured again, and an action list of improvement proposals is attained. To implement the updated procedure progressively, a pilot series can be set up to validate the measures applied. Finally, the work plan and final implementation are carried out.

VSM/VSD methodology has been widely applied in multiple organizations and industries. Several articles have been reviewed in the literature, not only considering specific industries [47] but also including different sectors [48,49]. Processes of a wide number of case studies demonstrated the benefits of this lean technique. For example, from the automotive and transportation industry, Wee et al. presented VSM as an effective tool to systematically analyze a lean supply chain problem [50]. Lead time and cycle time were reduced in process lines of auto-parts [51,52] and manufacturing cells [53]. Other manufacturing sectors with confirmed performance results after VSM/VSM applications are plastic injected products used in the healthcare industry [54] and textile and apparel companies [55]. Authors in [56] analyzed traditional steel production processes used in appliance manufacturing and demonstrated the suitability of VSM lean technique and simulation models to evaluate the implemented configurations. Additional case studies with VSM/VSD application with satisfactory results were the industrial paint manufacturing case presented in [57] and the fishing net production company of [58]. Nowadays, a new approach of VSM/VSD related to Industry 4.0 is also under study [59], considering the modeling of internal logistics data [60] or integrating the VSM methodology with a system dynamics analysis [61].

Supply chain challenges in the consumer goods sector were addressed in [62] and [63] to improve two particular processes in the wine and agri-food industry, respectively. The success of value stream mapping is, for example, also demonstrated in product development phases [64], logistical system design [65], software development [66], and service industries [67], so that the universality of this lean technique is worthy of note. Finally, other applications of value stream analysis focused on environmental, waste reduction [68], or manufacturing sustainability performance improvement [69-71] are presented in the bibliography, and also social and economic sustainability issues are targeted with value stream analysis [72-74]. 
Additionally, new approaches for VSM have been presented in the literature. Haefner et al. [75] included in the VSM analysis quality assurance measures to reduce the rate of defects and quality-related costs. Toivonen et al. [76] introduced in the value stream analysis innovative principles, such as TRIZ and ideation tools, for improving complex processes with a holistic understanding of systems. In [77], a holistic and multi-level VSM approach is presented for multiple sectors. The authors in [78] proposed a similar VSM analysis but, particularly, for information streams in a demanding production case environment.

However, thorough research revealed the scarce academic publications on the evaluation of lean techniques, such as VSM/VSD, applied to the military field and to their logistics processes. In this work, the case study addresses the use of lean tools, such as VSM/VSD, in military logistic processes to improve the material order processing lead-time as a key performance metric of the $\mathrm{ABC}$ organization.

\section{Methodology}

To structure the research, DMAIC (define-measure-analyze-improve-control) methodology was followed, whose principles are aligned to kaizen or continuous improvement in lean thinking. DMAIC is a structured procedure used in Six Sigma and often described as a problem-solving approach [79] to improve manufacturing and business processes by minimizing their variability when focusing on defects and their causes. Six Sigma projects using DMAIC and their benefits are widely demonstrated in the literature [79-83], even with application to SCM [83,84]. Some examples of Lean Six Sigma in military context were found. In [85], the author analyses the application of Lean Six Sigma (LSS) within the Department of Defense (DoD), providing some examples of implementation of this methodology in the United States army, navy, and air force. In the same direction, Baily et al. [86] applied LSS in an army depot maintenance and support processes of command and control systems across the Department of Defense (DoD), reducing the number of repeated material runs for end items and raw materials by $50 \%$ in the depot machine shop.

In this work, value stream analysis was integrated into the Six Sigma DMAIC structure for the project, as is shown in Figure 1. We defined a list of the activities planned in the project that was structured into the five DMAIC phases. In addition, a definition of the lean tools selected for the project was done, focusing mainly on Gemba Walk for the process audit, and value stream mapping (VSM)-value stream design (VSD) for the supply process analysis and optimization.

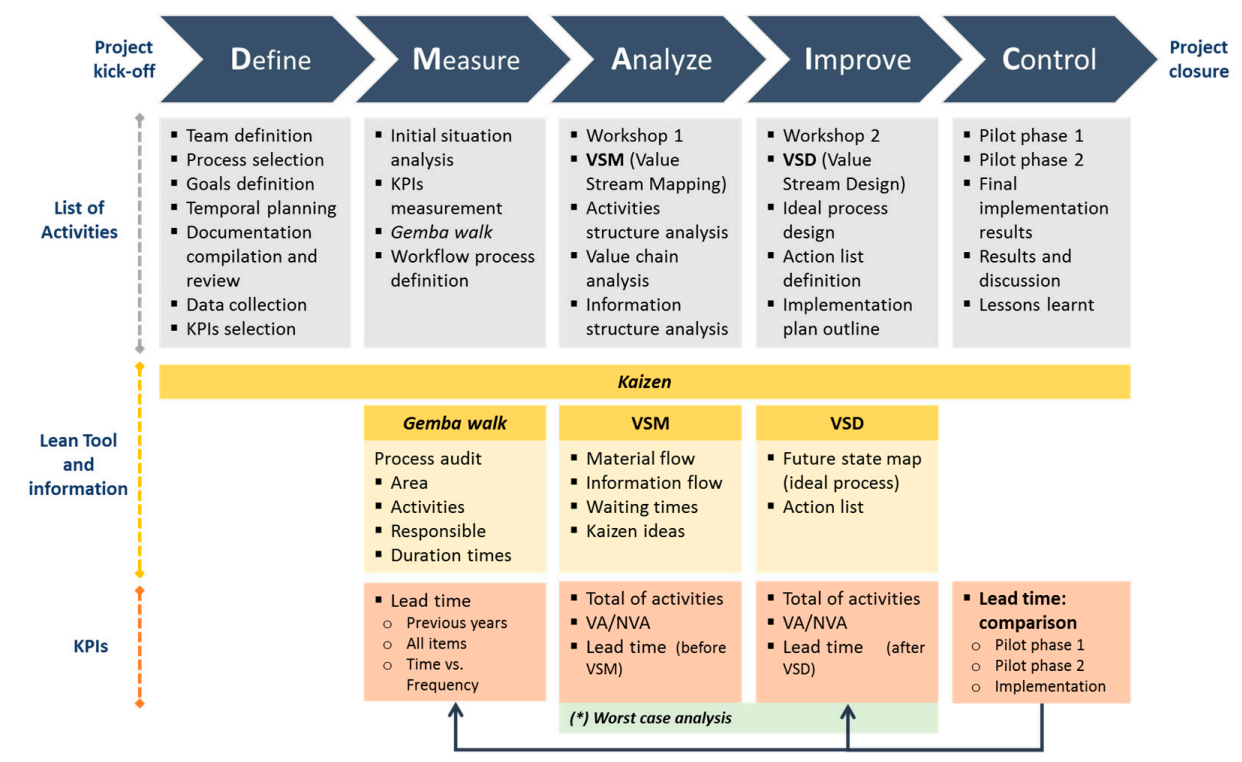

Figure 1. Define-measure-analyze-improve-control (DMAIC) project structure: lean tools and project activities. 


\section{Case Study}

As previously said, $\mathrm{ABC}$ is a military unit in charge of the supply of a wide range of spare parts. Due to the importance of response times for armed forces purposes, the selected process to be improved is the order processing of spare parts and new materials that military units deployed in national and international locations demand. Therefore, the study is focused on the procedure between the order generation from a military unit that requests the material and transportation to the final destination.

In the Define phase of DMAIC and after the constitution of the project team, the process under study was selected, and data collection was done from the registered information in the main database of $A B C$. In this case, we considered the orders, which are processed daily by the ABC unit. The key performance indicator (KPI) of the process to be optimized is the lead-time of the order fulfillment. Thus, it was assumed the lead-time of the process was the sum of not only the order's processing time but also waiting times that could produce delays or intermediate stocks along the process. Due to the different activities carried out in the process, the complete lead-time was also subdivided into several intermediate times that were measured. In particular, the lead-time used in this work was calculated from the date when $A B C$ received the order until the date when the delivery notification was sent to the requesting military unit.

Once the process to be analyzed and its reference KPIs were defined, the goals of the project could be established. The organization $\mathrm{ABC}$ initially proposed to reduce the lead-time of the order processing at the end of the project up to 0.5 days. Additionally, the following requirements and targets are settled:

- Non-value added activities in the supply process should be identified.

- The affected areas of the process and the required times of their activities should be evaluated.

- General process improvements should be identified and the effectiveness of the actions proposed should be validated.

- The new procedure should be documented by redefining activities, workflow, responsibilities, and layouts.

- The requirements established by their own organization should be guaranteed.

The analysis of the current performance of $A B C$ was carried out in the measure phase based on the historical data of the years: 2014, 2015, and 2016. The ABC unit handles an average of 15,000 orders per year, which could correspond, independently, to requests from a national territory or from the operation zone. Based on the origin of the order, a priority is assigned. The initial study calculated the average lead-time of the process before the lean optimization to establish a reference value as a zero point for the lead-time indicator. The values calculated for 2015 were 6.76 days for the average lead-time and 6.74 days for the standard deviation of the process in the study. It is worth mentioning the high dispersion of the values measured. Therefore, an additional target for minimizing the high variability of the process was settled.

Additionally, the main incidences in terms of time and frequency, material parts affected, and their potential causes were identified. In this way, an analysis of critical materials was carried out for the most representative period (January to June 2016). It can be concluded that $5 \%$ of the material orders were completed on the same day that the supply order was generated from the unit. However, there were critical materials with relatively high values of lead-time. As shown in Figure 2a, among all the materials ordered from January to June 2016, 3\% of those material numbers had a lead-time greater than 9 days. This value has been considered as critical after the analysis of lead times in years 2015 and 2016, in terms of average lead-time and standard deviation. These relatively high average lead time values resulted from having materials with high peak lead time values and low ordering frequency, or high ordering frequencies with more moderate lead times. The representation of the different areas cited according to the problems associated with the material (high lead-time or high ordering frequencies) is shown in Figure 2b. These materials were analyzed individually, and specific action plans were defined, given their big influence in the global lead-time indicator of the process. 
a) 2016 - Critical materials

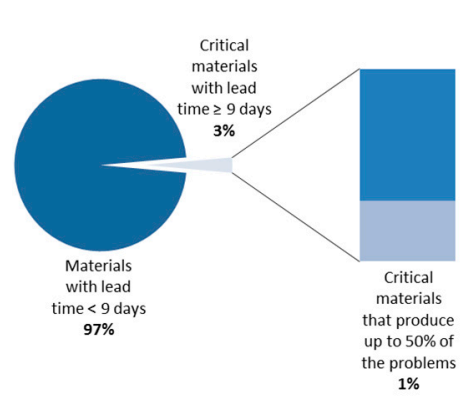

b) 2016 - Lead time vs. Ordering frequency

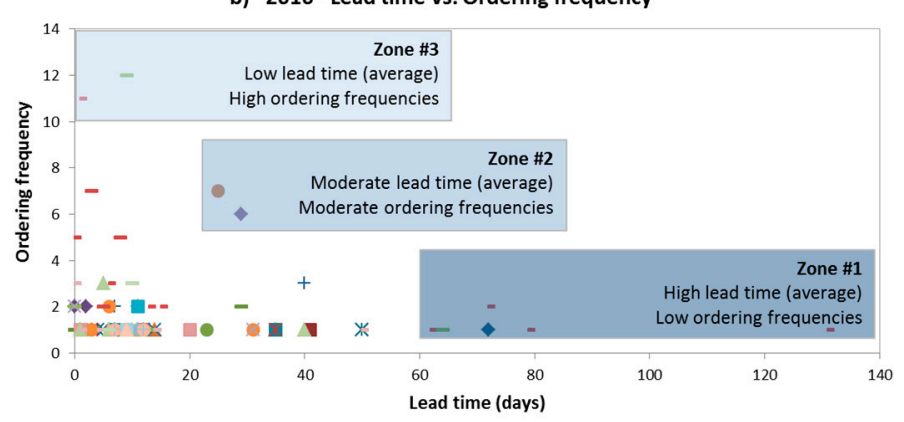

Figure 2. (a) Critical materials global analysis (2016); (b) Lead time vs. ordering frequency of critical materials (2016).

\subsection{Current State Map}

Gemba is the lean term related to the "go-and-see" principle that refers to "real place", where the work is happening. Hence, Gemba walk is the tool to analyze processes with concerned people by observation at the value-add location. This also served as an opportunity to discover Kaizen ideas, whereas the different areas, managers, tasks, and estimated times are recorded from the last process activity to the first one. In this case study, three departments of the supply chain were audited: the supply chain control office, the internal material warehouse, and the expedition area to the final military unit. There are approximately 15 employees working in these departments, with 8 am to $3 \mathrm{pm}$ working shifts five days a week. Gemba walk finished with the workflow diagram generation of the material order process in the $A B C$ unit. This diagram represents all the activities revised given the affected departments and considering the critical path. This critical path is the worst-case process in terms of time (longest lead time) and number of tasks (highest number of activities and intermediate waiting times).

Integrated into the analyze phase and after the workflow diagram definition, the activities structure was analyzed. In this case, 48 activities encompass the current material ordering process, being 21 classified as value-added (VA), 21 as non-value added (NVA), and 6 as semi-value added (SVA). In addition, different types of wastes were identified in the process, representing the over-processing of the material order in the different areas, a percentage of $54 \%$ out of the total mudas or wastes identified in the process. It was clearly seen that overwork or redundant verifications were handled systematically along the process. Other remarkable wastes were the waiting times between operations or sub-processes $(22 \%)$ and the reworks $(13 \%)$ due to failures in the process. Based on this analysis, one of the focuses in the VSM/VSD was to eliminate redundancies that affect clearly the final lead-time of the process.

Once the classification and time of all the tasks were defined, and the complete workflow finished, the process timeline was obtained, and the key performance indicators of VSM were calculated. This is shown in Figure 3, where the ABC current state map is simplified to summarize the results obtained: total and added value activities, lead-time, and kaizen ideas associated with each area of the process.

The VSM confirms the excessive material transport and high administrative workload detected in the process because of the established organization procedures. Nevertheless, both aspects might be improved in the ideal case. In summary, five waiting times were identified in the material order processing procedure of $\mathrm{ABC}$ representing these inventories 13.84 days that the material order could be blocked in a worst-case scenario. This could be due to delays in order's endorsement from superiors, pending transport approvals, or further calibration and testing of the order's material. Over the VSM represented in the swim lane diagram, 20 kaizen ideas were tagged. The sequence of the activities presented in the current state map supposes a lead-time of the process of 49.73 days. If the relation between added value (VA) and non- and semi-added value (NVA + SVA) is calculated, the obtained percentage is $1.57 \%$. This result indicates the high improvement margin that exists in the process, 
taking into account the small percentage of activities effectively devoted to the processing of the order and material requested.

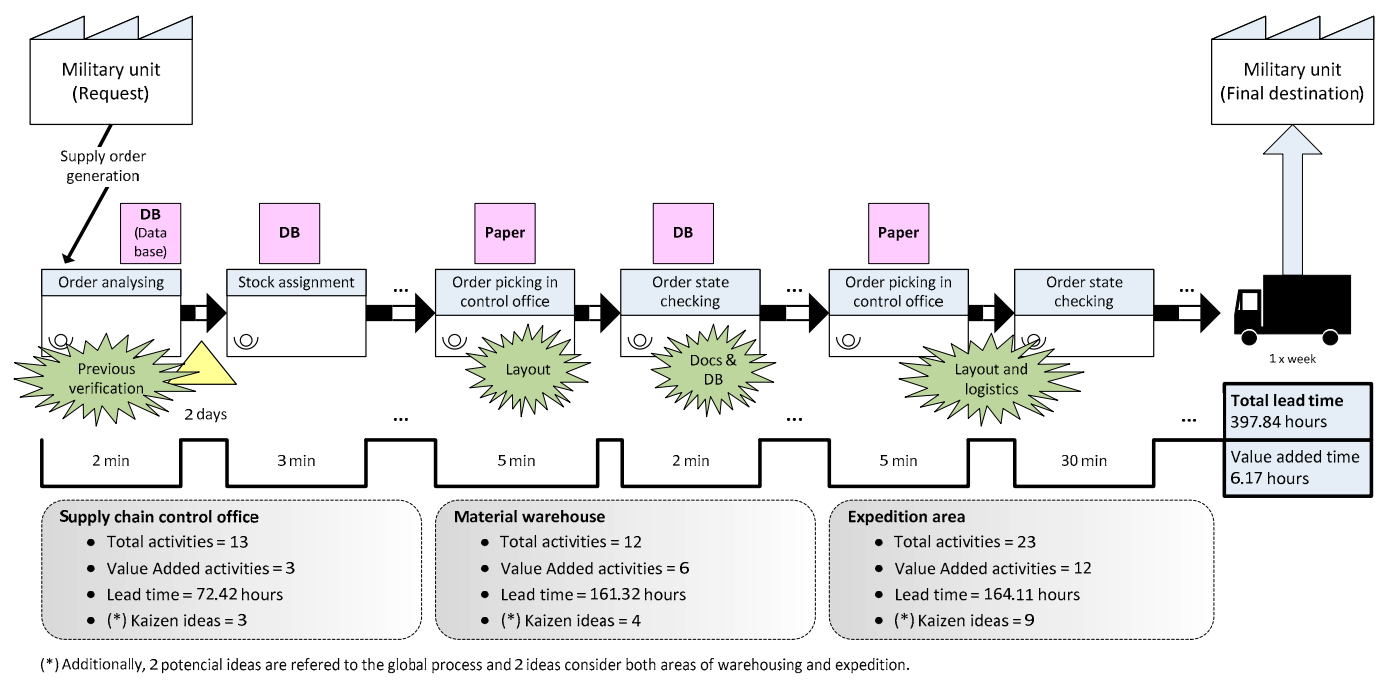

Figure 3. Value stream mapping (VSM) for material order processing procedure: simplified current state map.

The information flow and the mechanisms used are also a key issue to be analyzed and optimized with the value stream mapping. Those mechanisms were indicated in the current state map, and the potential ideas to improve the value-added in the information tasks were included in the action list. The information flow from customers, the military unit that requested the material in this case, to the $A B C$ unit, was standardized in the official information technology (IT) logistic information system of the army. The $\mathrm{ABC}$ personnel proposed a vast range of optimizations in the information loading process in the IT system. In addition, hard copies of the IT material order registered in the system were unnecessarily printed, used as working paper along the process, and finally stored. This could be easily solved by working only with the soft order in the IT logistics system. In this line, massive changes in the main SCM information system and future elimination of additional existing databases were considered.

\subsection{Future State Map}

The design of the ideal process consists of defining and listing the activities that could improve the material order and information processing flow, according to the critical points and potential upgrades identified in the VSM analysis. All these activities are covered in the improve phase of DMAIC. The degree of improvement is measured by the indicators, i.e., lead-time of the process. Hence, to meet the requirement of minimizing the lead-time, we carried out different actions to increase the value of the process. This was achieved by involving people and key partners, optimizing the current activities, and eliminating and/or minimize waiting times and inventories between tasks to create flow [34].

With the new list of process activities, the future state map out of value stream design (VSD) is schematized in Figure 4, where the improvement obtained in the total lead-time of the complete process is worthy of note.

The comparison between the indicators measured before VSM and after VSD is shown in Table 1 and Figure 5. The number of activities was reduced up to $56 \%$ from 48 to 27 , by minimizing NVA activities (from 21 to 5) and SVA activities (from 6 to 3). Therefore, the value-added of the process was increased. Considering the number of activities, VA tasks suppose $70 \%$ of the whole process after VSD. The ratio between added value and non-added value operations is for the ideal situation, $48.86 \%$. This shows the optimization in terms of value in the whole process. The lead-time of the process was also minimized from 49.73 days to 0.75 days. In brief, the presented results indicate that the 
order processing procedure could be noticeably improved theoretically, by implementing the proposed actions. As a result, the $\mathrm{ABC}$ unit would be able to complete an order in less than one day in the ideal process situation.

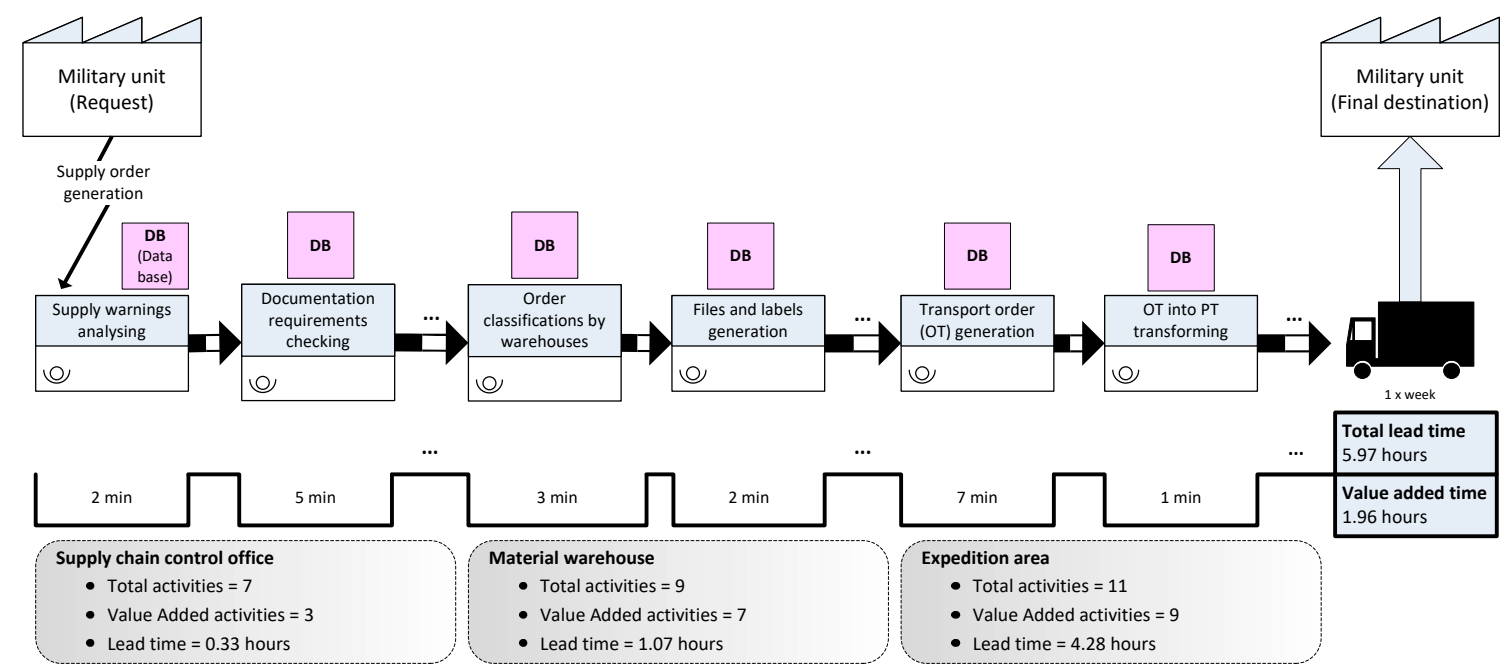

Figure 4. Value stream design (VSD) for order processing procedure: simplified future state map.

Table 1. Process indicators before value stream mapping (VSM) and after value stream design (VSD).

\begin{tabular}{ccc}
\hline Indicator & Before VSM & After VSD \\
\hline Total activities & 48 & 27 \\
VA activities (\%) & $21(44 \%)$ & $19(70 \%)$ \\
NVA activities (\%) & $21(44 \%)$ & $5(19 \%)$ \\
SVA activities (\%) & $6(12 \%)$ & $3(11 \%)$ \\
VA (hours) & 6.17 & 1.96 \\
NVA (hours) & 391.68 & 4.01 \\
VA/[NVA + SVA] (\%) & $1.57 \%$ & $48.86 \%$ \\
Lead Time (hours) & 397.84 & 5.97 \\
Lead Time (days) & 49.73 & 0.75 \\
\hline
\end{tabular}

Notation: VA (value added), NVA (non-value added), SVA (semi- value added).
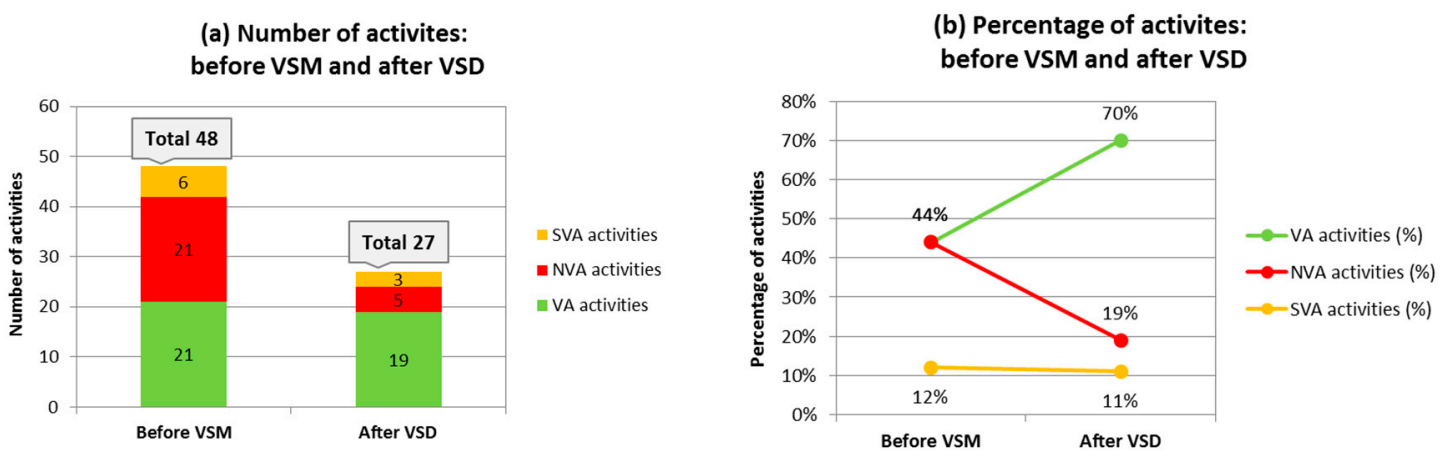

Figure 5. Results before VSM and after VSD: (a) Number of activities comparison; (b) Indicators of activities percentage.

Both kaizen value-stream improvement focused on material and information flow and process-level kaizen consisting of elimination of waste at the shop floor level were targeted. The summarized outcomes of the future state map are the following: (i) optimize material transport routes and procedures between warehouse and expedition area, (ii) eliminate redundant material checking and identification tasks, (iii) establish new standardized procedure for daily routine between the supply 
chain control office and the warehouse, (iv) personnel capacity balancing among departments based on tasks redesign and new assignment plan, (v) design of new material pick-up routes in the warehouse based on material location and volumes, (vi) generation of change requests package for routine administrative tasks in IT army logistics information system affecting the material order processing procedure, (vii) improve the information system of the process by elimination of material order printed documentation, (viii) elimination of waiting times between departments affected, (ix) monitoring and control of primary indicators of the process systematically, $(x)$ increase visual management in the whole process.

\subsection{Implementation Plan Outline}

The kaizen improvement ideas were included in the action list, where responsibilities and affected tasks were defined. Thus, there were 20 actions to be implemented to achieve the ideal process defined in the VSD. All of them were carefully analyzed by the organization and the owner of the process to evaluate their impact, resources needed, and potential risks to be avoided using a contingency plan. Ideas that demanded capital expenditure were limited since the study was carried out in the middle of the year, and the budget of the $A B C$ unit was limited. This analysis ended with the definition of the implementation plan for the new actions.

Value stream design concludes with the theoretical results obtained for the new ideal process. Nevertheless, to validate these results, the implementation of this new, improved process should be attained. As the different proposals for process change were not easy to implement at once and to validate them progressively, two pilot phases of implementation were defined in $A B C$ before the complete deployment of the action plan in the whole process. Both pilot phases were extended in time approximately for 10 working days. The affected number of orders and associate material references were incremented progressively from phase 1 to phase 2, being arbitrarily selected in both phases. In brief:

- Pilot phase 1: 11 working days, $26.4 \%$ of the total request orders processed with the new process, 143 different types of material references.

- Pilot phase 2: 10 working days, $53.0 \%$ of the total request orders processed with the new process, 200 different types of material references.

Thus, in the next DMAIC control phase, we included the analysis of the indicators obtained in the pilot implementation phase as an important input to confirm if the project copes with the initially established requirements.

At the end of pilot phase 1, the method used for evaluating the effectiveness of the improved process implementation was hypothesis testing or sometimes referred to as significance testing. Hence, the research hypothesis $\left(\mathrm{H}_{0}\right)$ was that the new procedure is related to the minimization of the lead-time value. Two groups were defined, given the processed orders considering procedures, the previous one and the new proposed. Additionally, pre-test and post-test differentiation were made with regards to orders included before and during the pilot phase 1, respectively. A parametric test was considered due to the accomplishment of the following assumptions: randomness of the sample observations, normality (central limit theorem), homogeneity of sample variances from the same population. A Student's $t$-test was applied, considering the $95 \%$ confidence interval to test a hypothesis about two means. Table 2 shows the results of the test, including the lead-time by orders. Given the significance obtained, in both cases, the value of 0.05 was not exceeded, $\mathrm{H}_{0}$ could not be rejected. Then, the pilot phases continue with phase 2 . 
Table 2. Significance testing results considering pilot phase 1 .

\begin{tabular}{ccccccc}
\hline Study Groups & $\begin{array}{c}t \text {-Test for Equality of } \\
\text { Means }\end{array}$ & $t$ & $\begin{array}{c}\text { Freedom } \\
\text { Degrees }\end{array}$ & $\begin{array}{c}\text { Sig. } \\
\text { (2-Tailed) }\end{array}$ & $\begin{array}{c}\text { Mean } \\
\text { Difference }\end{array}$ & $\begin{array}{c}\text { Std. Error } \\
\text { Difference }\end{array}$ \\
\hline $\begin{array}{c}\text { Post-test } \\
\begin{array}{c}\text { Experimental group } \\
\text { and control group }\end{array}\end{array}$ & $\begin{array}{c}\text { Equal variances } \\
\text { assumed } \\
\text { Equal variances not } \\
\text { assumed }\end{array}$ & -3.56 & 608 & 0.000 & -0.614 & 0.172 \\
\hline $\begin{array}{c}\text { Experimental group } \\
\text { Pre-test and Post-test }\end{array}$ & $\begin{array}{c}\text { Equal variances } \\
\text { assumed }\end{array}$ & 5.40 & 518.9 & 0.001 & -0.614 & 0.176 \\
\hline $\begin{array}{c}\text { Equal variances not } \\
\text { assumed }\end{array}$ & 18.18 & 733.2 & 0.000 & 2.243 & 0.123 \\
\hline
\end{tabular}

\section{Results}

The KPIs obtained for both implementation phases are shown in Figure 6, considering the total number of orders processed by ABC during the year 2016, and the ones processed in the two pilot implementation phases. The lead-time was significantly improved in the new VSD process (pilot phase 1 and pilot phase 2). If we compare the current and implemented process (2016 data), the lead time mean value was reduced by half approximately, as can be seen in Figure 6. Additionally, its deviation was also improved, achieving a reduction value of $76 \%$.

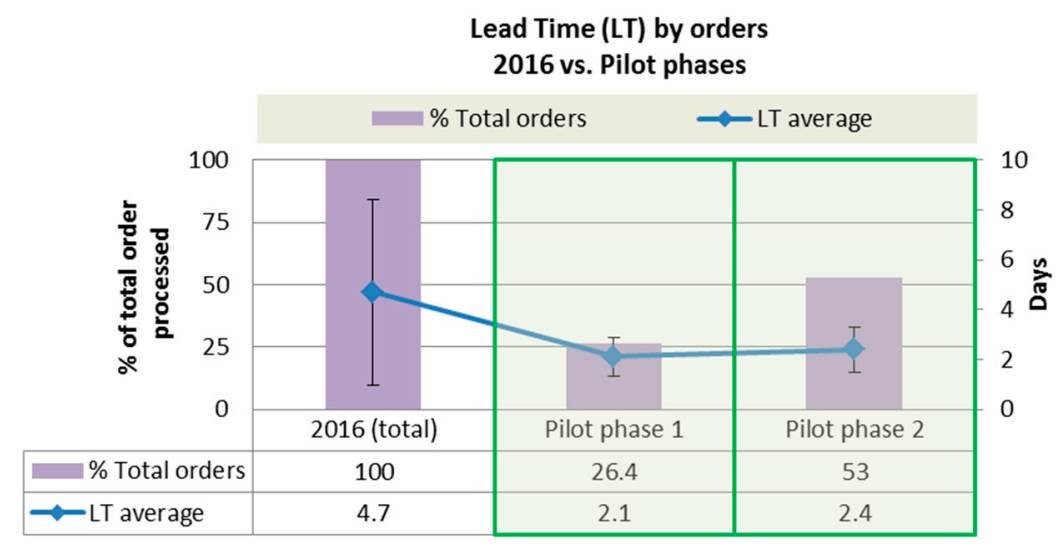

Figure 6. Pilot phases results: lead-time by orders.

Due to the fact that the different orders might not be comparable in terms of requested and type of material, a specific analysis considering material references is also presented. In this case, the material references included in each pilot phase were compared to the same material references behavior with the old process before VSM/VSD (2016 data in Figure 7). As is shown in Figure 7, the improvement in the average lead-time and deviation was proved in both pilot phases. In pilot phase 1 (see Figure 7, left), the results showed an improvement in the average lead-time of $45.24 \%$, and the standard deviation of the lead-time value decreased $39.13 \%$. During the pilot phase 2, when the new process was extended to more material orders processed by $\mathrm{ABC}$ (see Figure 7, right), the average lead-time improved $50 \%$, and the dispersion of the process measured with the lead-time standard deviation indicator showed a $29.17 \%$ improvement. As it was mentioned before, it was not only important to reduce the lead time of the material ordering process of $\mathrm{ABC}$ to optimize their fulfillment delivery to the external units but also to minimize the variability of the process. It is important to highlight that no increase in the orders reject rate was detected after the implementation of the VSD new process in the pilot series. Figure 8 represents the improvement achieved by comparing the lead-time vs. ordering frequency by material reference before and after implementation pilot phases. Despite the limited number of references and quantities analyzed (y-axis), the lead time values calculated for the materials included in the orders processed under the new procedure showed a clear reduction. It is proved that for the same materials the actions considered provided better performance results in terms of delivery fulfillment. 

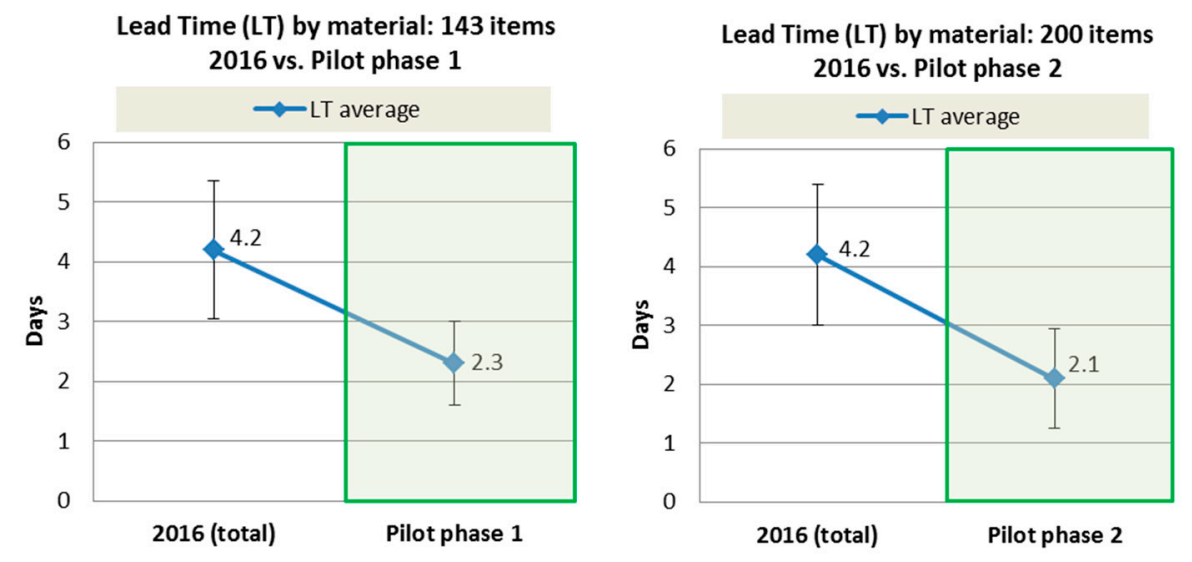

Figure 7. Pilot phases results: lead-time by material reference.

(a) Material references before pilot phases implementation

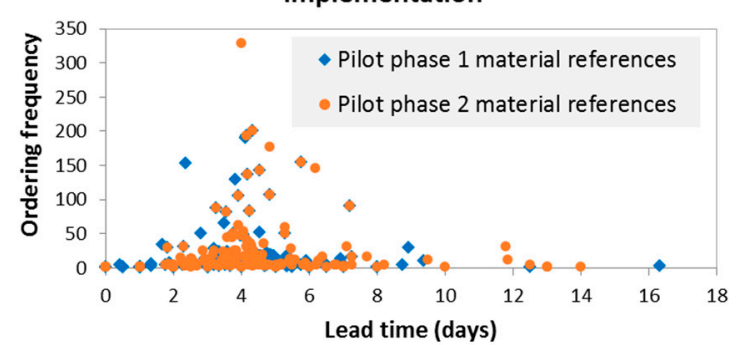

(b) Material references after pilot phases implementation

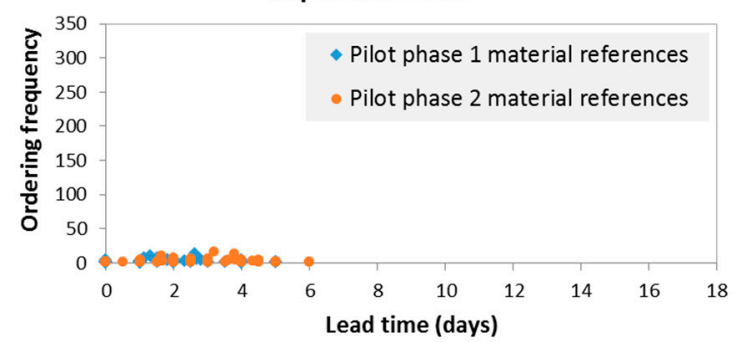

Figure 8. Pilot phases results: Lead-time vs. ordering frequency by material reference (a) before and (b) after implementation pilot phases.

As a last step of the VSM/VSD, the new procedure designed with the VSD, validated with the two pilot implementation phases, was applied to the $100 \%$ of the material orders from January 2017 onwards covering approximately 7800 orders after considering all the action list proposals. The following results confirm the positive degree of improvement in the $\mathrm{ABC}$ material order processing procedure with the application of lean methodologies. The temporal evolution in the lead-time (average and standard deviation) is represented in Figure 9, where the relative variation is shown in percentage considering the last four years (2014-2017). It is demonstrated that the KPIs of the process, including the VSM/VSD results, show an improvement. After the implementation phase in 2017, the average lead-time and deviation were reduced up to $69.6 \%$ and $61.9 \%$, respectively, considering the initial situation in 2014 . The results also confirmed the data obtained in both pilot implementation phases. Therefore, the KPIs behavior in the year 2017 after the complete implementation of the VSM/VSD actions in the process improved successfully.

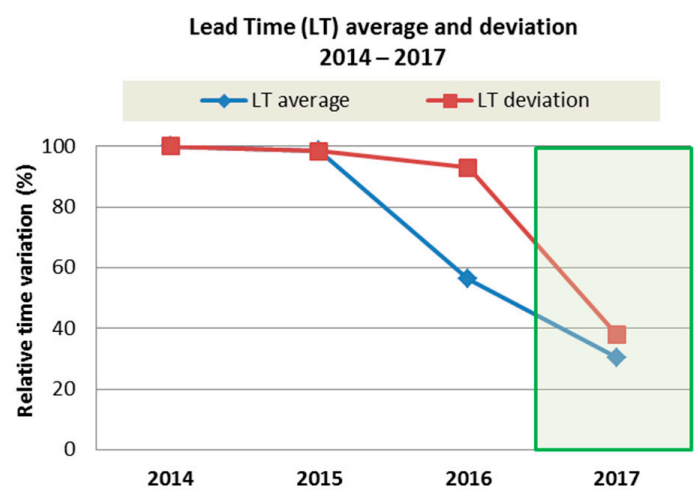

Figure 9. Temporal evolution in percentage terms of average lead-time and deviation (2014-2017). 
Thus, we can conclude that the application of the lean tools VSM/VSD to the material order processing procedure carried out in the ABC military organization was correctly implemented, clearly improved the average lead-time of the process, and reduced its standard deviation showing an evident improvement in its variability.

\section{Discussion}

This work presents the implementation of lean methodology value stream analysis in a particular case of military logistic processes. Specifically, the lean methodology value stream analysis (VSM/VSD) was applied satisfactorily to the material order processing procedure, which plays a key role in the ABC military organization supply chain. First, the state-of-art study showed that there is a lack of references with the same purpose and field of application. Although lean tools, such as VSM/VSD, are widely used in the industry, military issues are not so common in the literature when relating lean thinking and logistics. In addition, the case study is characterized by the special operating conditions. The high number of material references, the absence of demand patterns, and the high variation of the spare parts orders were the main challenges faced during the project.

The critical activities of the process were identified, and the times invested in each task together with the value-added in the affected areas were assessed. Therefore, we carried out a complete evaluation of the value-added chain of the order processing procedure in the project. This was extremely important to define the key activities to eliminate, improve, or redefine with the ultimate target of increasing the value-added of the complete supply chain. Kaizen ideas were detailed to illustrate the solution strategy proposed for this project. The development of a lean logistics concept, eliminating the waste and increasing the added value of the spare parts supply process, enables the improvement in the delivery fulfillment of the $A B C$ organization to the requesting military units, qualifying the correct achievement of their missions in national territory or operation zone.

The implementation of the two pilot phases of the ideal VSD process performed successfully showing a clear improvement in the key performance indicators. The validation of the actions derived from VSM/VSD in the test period was decisive to finally decide the implementation in the complete order processing procedure from the beginning of 2017. After the ideal VSD process deployment, the results indicated that the future state map could increase added-value activities from $44 \%$ to $70 \%$, and the average and deviation of the lead-time was reduced up to $69.6 \%$ and $61.9 \%$, respectively, from 2014 to 2017.

The integration of analytical tools to evaluate the system variation, including modeling and simulation of the system before and after the value stream analysis application is recommended as future activities and research lines. The implementation of the lean management approach presented in this work in a military logistics procedure highlights the need for reinforcing these practices in the military context. According to the obtained results, we can also conclude that lean methodologies could be further extended to other military logistics processes and units with the ultimate target of improving the military unit's delivery fulfillment.

Author Contributions: Conceptualization R.A., M.T.; Validation: R.P.-M., J.A.P.; Methodology, R.A., M.T.; Investigation, R.A., M.T., R.P.-M., J.A.P.; Resources, R.P.-M., J.A.P.; Writing-Original Draft Preparation, R.A., M.T.; Writing-Review and Editing, R.P.-M., J.A.P. All authors have read and agreed to the published version of the manuscript.

Funding: This research was funded by the Centro Universitario de la Defense (Zaragoza-Spain) via project number CUD 2015-21 and by Aragon Government through the Research Activity Grant for research groups.

Acknowledgments: The authors thank the ABC military organization unit for providing the case study and their collaboration.

Conflicts of Interest: The authors declare no conflict of interest. 


\section{References}

1. The Wharton School, University of Pennsylvania. Managing Supply Chains: What the Military Can Teach Business (and Vice Versa). Available online: http://knowledge.wharton.upenn.edu/article/managing-supplychains-what-the-military-can-teach-business-and-vice-versa/ (accessed on 17 July 2017).

2. Lai, E.M. An Analysis of the Department of Defense Supply Chain: Potential Applications of the Auto-ID Center Technology to Improve Effectiveness. Ph.D. Thesis, Department of Mechanical Engineering, Massachusetts Institute of Technology, Cambridge, MA, USA, 2003.

3. Joint Vision 2020. In America's Military—Preparing for Tomorrow; US Government Printing Office: Washington, DC, USA, 2000.

4. Haraburda, S.; Col, B. Transforming military support processes from logistics to supply chain management. Army Sustain. 2016, 48, 12-15.

5. Stewart, G. Supply-chain operations reference model (SCOR): The first cross-industry framework for integrated supply-chain management. Logist. Inf. Manag. 1997, 10, 62-67. [CrossRef]

6. Huan, S.H.; Sheoran, S.K.; Wang, G. A review and analysis of supply chain operations reference (SCOR) model. Supply Chain Manag. Int. J. 2004, 9, 23-29. [CrossRef]

7. Muckstadt, J.A.; General, T.; Babbitt, G. Military Supply Chains: Five Principles for Managing Uncertainty; PTC Inc.: Boston, MA, USA, 2016.

8. Womack, J.P.; Jones, D.T.; Roos, D. The Machine that Changed the World: The Story of Lean Production; Harper Perennial: New York, NY, USA, 1991.

9. Liker, J.K. The Toyota Way: 14 Management Principles from the World's Greatest Manufacturer; McGraw Hill: New York, NY, USA, 2004.

10. Ohno, T. Toyota Production System: Beyond Large-Scale Production; Productivity Press: New York, NY, USA, 1988.

11. Shingo, S. Non-Stock Production: The Shingo System of Continuous Improvement; Productivity Press: Cambridge, MA, USA, 1988.

12. Burt, D.N.; Dobler, D.W.; Starling, S.L. World Class Supply Management: The Key to Supply Chain Management; McGraw-Hill/Irwin: New York, NY, USA, 2003; ISBN 0072290706.

13. Lysons, K.; Farrington, B. Purchasing and Supply Chain Management, 8th ed.; Pearson Education: London, UK, 2012.

14. O'Rourke, D. The science of sustainable supply chains. Science 2014, 344, 1124-1127. [CrossRef]

15. Lamming, R. Beyond Partnership: Strategies for Innovation and Lean Supply; Prentice Hall: Upper Saddle River, NJ, USA, 1993.

16. Lamming, R. Squaring lean supply with supply chain management. Int. J. Oper. Prod. Manag. 1996, 16, 183-196. [CrossRef]

17. Pande, P.S.; Neuman, R.P.; Cavanagh, R.R. The Six Sigma Way; McGraw-Hill: New York, NY, USA, 2000.

18. Imai, M. Kaizen: The Key to Japan's Competitive Success; McGraw-Hill Education: New York, NY, USA, 1986.

19. Harry, M.; Schroeder, R.R. Six Sigma: The Breakthrough Management Strategy Revolutionizing the World's Top Corporations; Doubleday Business: New York, NY, USA, 1999.

20. Arnheiter, E.D.; Maleyeff, J. The integration of lean management and Six Sigma. TQM Mag. 2005, 17, 5-18. [CrossRef]

21. Cherrafi, A.; Elfezazi, S.; Chiarini, A.; Mokhlis, A.; Benhida, K. The integration of lean manufacturing, Six Sigma and sustainability: A literature review and future research directions for developing a specific model. J. Clean. Prod. 2016, 139, 828-846. [CrossRef]

22. Tuttle, W., Jr. Defense Logistics for the 21st Century; Naval Institute Press: Annapolis, MD, USA, 2013.

23. NATO Standardization Agency. NATO Glossary of Terms and Definitions; CreateSpace Independent Publishing Platform: Scotts Valley, CA, USA, 2013.

24. Zhou, W.; Zhang, C.; Wang, Q. Concealment measurement and flow distribution of military supply transportation: A double-entropy model. Eur. J. Oper. Res. 2018, 264, 570-581. [CrossRef]

25. Kalchschmidt, M.; Zotteri, G.; Verganti, R. Inventory management in a multi-echelon spare parts supply chain. Int. J. Prod. Econ. 2003, 81, 397-413. [CrossRef]

26. Huiskonen, J. Maintenance spare parts logistics: Special characteristics and strategic choices. Int. J. Prod. Econ. 2001, 71, 125-133. [CrossRef] 
27. Tysseland, B.E. Spare parts optimization process and results: OPUS10 cases in the Norwegian Defence. Int. J. Phys. Distrib. Logist. Manag. 2009, 39, 8-27. [CrossRef]

28. Gholz, E.; James, A.D.; Speller, T.H. The second face of systems integration: An empirical analysis of supply chains to complex product systems. Res. Policy 2018, 47, 1478-1494. [CrossRef]

29. Mayr, A.; Weigelt, M.; Kühl, A.; Grimm, S.; Erll, A.; Potzel, M.; Franke, J. Lean 4.0-A conceptual conjunction of lean management and Industry 4.0. Procedia CIRP 2018, 72, 622-628. [CrossRef]

30. Krafcik, J.F. Triumph of the lean production system. MIT Sloan Manag. Rev. 1988, 30, 41.

31. Shah, R.; Ward, P.T. Lean manufacturing: Context, practice bundles, and performance. J. Oper. Manag. 2003, 21, 129-149. [CrossRef]

32. Bhamu, J.; Sangwan, K.S.; Singh Sangwan, K. Lean manufacturing: Literature review and research issues. Int. J. Oper. Prod. Manag. 2014, 34, 876-940. [CrossRef]

33. Sundar, R.; Balaji, A.N.; Kumar, R.M.S. A Review on Lean Manufacturing Implementation Techniques. Procedia Eng. 2014, 97, 1875-1885. [CrossRef]

34. Netland, T.H.; Schloetzer, J.D.; Ferdows, K. Implementing corporate lean programs: The effect of management control practices. J. Oper. Manag. 2015, 36, 90-102. [CrossRef]

35. Pearce, A.; Pons, D. Advancing lean management: The missing quantitative approach. Oper. Res. Perspect. 2019, 6, 100114. [CrossRef]

36. Wahab, A.N.A.; Mukhtar, M.; Sulaiman, R. A Conceptual Model of Lean Manufacturing Dimensions. Procedia Technol. 2013, 11, 1292-1298. [CrossRef]

37. Hines, P.; Holweg, M.; Rich, N. Learning to evolve. Int. J. Oper. Prod. Manag. 2004, 24, 994-1011. [CrossRef]

38. Rother, M.; Shook, J. Learning to See: Value Stream Mapping to Add Value and Eliminate Muda; The Lean Enterprise Institute: Brookline, MA, USA, 1998.

39. Bruce, M.; Daly, L.; Towers, N. Lean or agile: A solution for supply chain management in the textiles and clothing industry? Int. J. Oper. Prod. Manag. 2004, 24, 151-170. [CrossRef]

40. Christopher, M. The Agile Supply Chain. Ind. Mark. Manag. 2000, 29, 37-44. [CrossRef]

41. Naylor, J.B.; Naim, M.; Berry, D. Leagility: Integrating the lean and agile manufacturing in the total supply chain. Int. J. Prod. Econ. 1999, 62, 107-118. [CrossRef]

42. Martin, C.; Towill, D.R. Supply chain migration from lean and functional to agile and customised. Supply Chain Manag. Int. J. 2000, 5, 206-213. [CrossRef]

43. Minculete, G.; Olar, P. Push and Pull systems in supply chain management. Correlative approaches in the military field. J. Def. Resour. Manag. 2016, 7, 165-172.

44. Bean, W.L.; Joubert, J.W.; Luhandjula, M.K. Inventory management under uncertainty: A military application. Comput. Ind. Eng. 2016, 96, 96-107. [CrossRef]

45. Hines, P.; Rich, N. The seven value stream mapping tools. Int. J. Oper. Prod. Manag. 1997, 17, 46-64. [CrossRef]

46. Forno, A.J.D.; Pereira, F.A.; Forcellini, F.A.; Kipper, L.M. Value Stream Mapping: A study about the problems and challenges found in the literature from the past 15 years about application of Lean tools. Int. J. Adv. Manuf. Technol. 2014, 72, 779-790. [CrossRef]

47. Singh, B.; Garg, S.K.; Sharma, S.K. Value stream mapping: Literature review and implications for Indian industry. Int. J. Adv. Manuf. Technol. 2011, 53, 799-809. [CrossRef]

48. Shou, W.; Wang, J.; Wu, P.; Wang, X.; Chong, H.-Y. A cross-sector review on the use of value stream mapping. Int. J. Prod. Res. 2017, 55, 3906-3928. [CrossRef]

49. Seth, D.; Seth, N.; Dhariwal, P. Application of value stream mapping (VSM) for lean and cycle time reduction in complex production environments: A case study. Prod. Plan. Control 2017, 28, 398-419. [CrossRef]

50. Wee, H.M.; Wu, S. Lean supply chain and its effect on product cost and quality: A case study on Ford Motor Company. Supply Chain Manag. Int. J. 2009, 14, 335-341. [CrossRef]

51. Rahani, A.R.; Al-Ashraf, M. Production Flow Analysis through Value Stream Mapping: A Lean Manufacturing Process Case Study. Procedia Eng. 2012, 41, 1727-1734. [CrossRef]

52. Andrade, P.F.; Pereira, V.G.; Del Conte, E.G. Value stream mapping and lean simulation: A case study in automotive company. Int. J. Adv. Manuf. Technol. 2016, 85, 547-555. [CrossRef]

53. Venkataraman, K.; Ramnath, B.V.; Kumar, V.M.; Elanchezhian, C. Application of Value Stream Mapping for Reduction of Cycle Time in a Machining Process. Procedia Mater. Sci. 2014, 6, 1187-1196. [CrossRef] 
54. Rohac, T.; Januska, M. Value Stream Mapping Demonstration on Real Case Study. Procedia Eng. 2015, 100, 520-529. [CrossRef]

55. Hodge, G.L.; Ross, K.G.; Joines, J.A.; Thoney, K. Adapting lean manufacturing principles to the textile industry. Prod. Plan. Control 2011, 22, 237-247. [CrossRef]

56. Abdulmalek, F.A.; Rajgopal, J. Analyzing the benefits of lean manufacturing and value stream mapping via simulation: A process sector case study. Int. J. Prod. Econ. 2007, 107, 223-236. [CrossRef]

57. Rohani, J.M.; Zahraee, S.M. Production Line Analysis via Value Stream Mapping: A Lean Manufacturing Process of Color Industry. Procedia Manuf. 2015, 2, 6-10. [CrossRef]

58. Yang, T.; Kuo, Y.; Su, C.T.; Hou, C.L. Lean production system design for fishing net manufacturing using lean principles and simulation optimization. J. Manuf. Syst. 2015, 34, 66-73. [CrossRef]

59. Hartmann, L.; Meudt, T.; Seifermann, S.; Metternich, J. Value stream method 4.0: Holistic method to analyse and design value streams in the digital age. Procedia CIRP 2018, 78, 249-254. [CrossRef]

60. Knoll, D.; Reinhart, G.; Prüglmeier, M. Enabling value stream mapping for internal logistics using multidimensional process mining. Expert Syst. Appl. 2019, 124, 130-142. [CrossRef]

61. Stadnicka, D.; Litwin, P. Value stream mapping and system dynamics integration for manufacturing line modelling and analysis. Int. J. Prod. Econ. 2019, 208, 400-411. [CrossRef]

62. Jiménez, E.; Tejeda, A.; Pérez, M.; Blanco, J.; Martínez, E. Applicability of lean production with VSM to the Rioja wine sector. Int. J. Prod. Res. 2012, 50, 1890-1904. [CrossRef]

63. De Steur, H.; Wesana, J.; Dora, M.K.; Pearce, D.; Gellynck, X. Applying Value Stream Mapping to reduce food losses and wastes in supply chains: A systematic review. Waste Manag. 2016, 58, 359-368. [CrossRef]

64. Tyagi, S.; Choudhary, A.; Cai, X.; Yang, K. Value stream mapping to reduce the lead-time of a product development process. Int. J. Prod. Econ. 2015, 160, 202-212. [CrossRef]

65. Kaiser, J.; Urnauer, C.; Metternich, J. A framework for planning logistical alternatives in value stream design. Procedia CIRP 2019, 81, 180-185. [CrossRef]

66. Ali, N.B.; Petersen, K.; De França, B.B.N. Evaluation of simulation-assisted value stream mapping for software product development: Two industrial cases. Inf. Softw. Technol. 2015, 68, 45-61. [CrossRef]

67. Grove, A.L.; Meredith, J.O.; Macintyre, M.; Angelis, J.; Neailey, K. Lean implementation in primary care health visiting services in National Health Service UK. Qual. Saf. Health Care 2010, 19, e43. [CrossRef]

68. Garza-Reyes, J.A.; Torres Romero, J.; Govindan, K.; Cherrafi, A.; Ramanathan, U. A PDCA-based approach to Environmental Value Stream Mapping (E-VSM). J. Clean. Prod. 2018, 180, 335-348. [CrossRef]

69. Faulkner, W.; Badurdeen, F. Sustainable Value Stream Mapping (Sus-VSM): Methodology to visualize and assess manufacturing sustainability performance. J. Clean. Prod. 2014, 85, 8-18. [CrossRef]

70. Helleno, A.L.; de Moraes, A.J.I.; Simon, A.T. Integrating sustainability indicators and Lean Manufacturing to assess manufacturing processes: Application case studies in Brazilian industry. J. Clean. Prod. 2017, 153, 405-416. [CrossRef]

71. Deshkar, A.; Kamle, S.; Giri, J.; Korde, V. Design and evaluation of a Lean Manufacturing framework using Value Stream Mapping (VSM) for a plastic bag manufacturing unit. Mater. Today Proc. 2018, 5, 7668-7677. [CrossRef]

72. Kasava, N.K.; Yusof, N.M.; Khademi, A.; Saman, M.Z.M. Sustainable domain value stream mapping (SdVSM) framework application in aircraft maintenance: A case study. Procedia CIRP 2015, 26, 418-423. [CrossRef]

73. Vinodh, S.; Ben Ruben, R.; Asokan, P. Life cycle assessment integrated value stream mapping framework to ensure sustainable manufacturing: A case study. Clean Technol. Environ. Policy 2016, 18, 279-295. [CrossRef]

74. Edtmayr, T.; Sunk, A.; Sihn, W. An Approach to Integrate Parameters and Indicators of Sustainability Management into Value Stream Mapping. Procedia CIRP 2016, 41, 289-294. [CrossRef]

75. Haefner, B.; Kraemer, A.; Stauss, T.; Lanza, G. Quality Value Stream Mapping. Procedia CIRP 2014, 17, 254-259. [CrossRef]

76. Toivonen, T.; Siitonen, J. Value Stream Analysis for Complex Processes and Systems. Procedia CIRP 2016, 39, 9-15. [CrossRef]

77. Oberhausen, C.; Plapper, P. Cross-enterprise value stream assessment. J. Adv. Manag. Res. 2017, 14, $182-193$. [CrossRef]

78. Roh, P.; Kunz, A.; Wegener, K. Information stream mapping: Mapping, analysing and improving the efficiency of information streams in manufacturing value streams. CIRP J. Manuf. Sci. Technol. 2019, 25, 1-13. [CrossRef] 
79. de Mast, J.; Lokkerbol, J. An analysis of the Six Sigma DMAIC method from the perspective of problem solving. Int. J. Prod. Econ. 2012, 139, 604-614. [CrossRef]

80. Parast, M.M. The effect of Six Sigma projects on innovation and firm performance. Int. J. Proj. Manag. 2011, 29, 45-55. [CrossRef]

81. Srinivasan, K.; Muthu, S.; Devadasan, S.R.; Sugumaran, C. Enhancing effectiveness of shell and tube heat exchanger through six sigma DMAIC phases. Procedia Eng. 2014, 97, 2064-2071. [CrossRef]

82. Nithyanandam, G.K.; Pezhinkattil, R. A Six Sigma approach for precision machining in milling. Procedia Eng. 2014, 97, 1474-1488. [CrossRef]

83. Cunha, C.; Dominguez, C. A DMAIC Project to Improve Warranty Billing's Operations: A Case Study in a Portuguese Car Dealer. Procedia Comput. Sci. 2015, 64, 885-893. [CrossRef]

84. Erbiyik, H.; Saru, M. Six Sigma Implementations in Supply Chain: An Application for an Automotive Subsidiary Industry in Bursa in Turkey. Procedia Soc. Behav. Sci. 2015, 195, 2556-2565. [CrossRef]

85. Hardy, D. An Analysis of Lean Six Sigma in the Army, Navy and Air Force; Naval Postgraduate School: Monterey, CA, USA, 2018.

86. Baily, A.; Gibson, B.; MacFarlane, J.M.; Hazelbaker, C.; Richards, J.; Lyle, I.; Rawhouser, B. Application of lean six sigma to reduce repeated handling of material at Tobyhanna Army Depot. In Proceedings of the 39th International Annual Conference American Society Engineering Management, ASEM 2018 Bridging Gap between Engineering and Business, Coeur d'Alene, ID, USA, 17-20 October 2018; pp. 691-700.

(C) 2019 by the authors. Licensee MDPI, Basel, Switzerland. This article is an open access article distributed under the terms and conditions of the Creative Commons Attribution (CC BY) license (http://creativecommons.org/licenses/by/4.0/). 